ISSN 1392-3196 / e-ISSN 2335-8947

Zemdirbyste-Agriculture, vol. 101, No. 4 (2014), p. 381-388

DOI 10.13080/z-a.2014.101.048

\title{
Analysis of grain yield and its components in spring triticale under different $\mathbf{N}$ fertilization regimes
}

\author{
Daiva JANUŠAUSKAITE் \\ Institute of Agriculture, Lithuanian Research Centre for of Agriculture and Forestry \\ Instituto 1, Akademija, Kèdainiai distr., Lithuania \\ E-mail: daiva.janusauskaite@1zi.lt
}

\begin{abstract}
Grain yield is a result of an organized interplay of several yield components, which are highly susceptible to environmental fluctuations. However, there is still a lack of knowledge about the relationship between grain yield and factors governing it. Experiments were conducted during the period 2008-2011 at the Institute of Agriculture, Lithuanian Research Centre for Agriculture and Forestry in Central Lithuania (55023'50" $\mathrm{N}$ and $23051^{\prime} 40^{\prime \prime}$ E) on an Endocalcari-Endohypogleyic Cambisol (CMg-n-w-can). The correlation coefficients and path coefficient analysis was done: i) to study the interrelationship between spring triticale grain yield and its components under different $\mathrm{N}$ fertilization regimes, ii) to establish the impact of meteorological factors on them, iii) to explain the causality of associations between the mentioned parameters through direct and indirect effects. Three nitrogen levels were used: i) without nitrogen $\left(\mathrm{N}_{0}\right)$, ii) $\mathrm{N}$ applied as basic fertilization shortly before sowing $\left(\mathrm{N}_{60-180}\right)$, iii) $\mathrm{N}_{90}$ and $\mathrm{N}_{150}$ rates split in two and three applications. Grain yield, yield components (ears $\mathrm{m}^{-2}$, grains ear ${ }^{-1}$, thousand grain weight) and meteorological factors were investigated. The results demonstrated that the interrelationship between grain yield and its components differed between $\mathrm{N}$ fertilization levels. Under single $\mathrm{N}_{60-180}$ fertilization, grain yield of spring triticale depended on ears $\mathrm{m}^{-2}$ and a thousand grain weight. Under split $\mathrm{N}_{90}, \mathrm{~N}_{150}$ level the yield depended on ears $\mathrm{m}^{-2}$. The correlation matrix between spring triticale grain yield and yield components did not reveal significant causality at $\mathrm{N}_{0}$ level. The character of interaction of grain yield components influenced the grain yield by $17.2 \%$ and $28.3 \%$ at single $\mathrm{N}_{60-180}$ and split $\mathrm{N}_{90}, \mathrm{~N}_{150}$ fertilization levels, respectively. However, such interaction was insignificant at $\mathrm{N}_{0}$ level. The growth and development of spring triticale responded to meteorological conditions more sensitively at single $\mathrm{N}_{60-180}$ and split $\mathrm{N}_{90}, \mathrm{~N}_{150}$ levels than at $\mathrm{N}_{0}$ level. At all $\mathrm{N}$ regimes, the weather conditions caused $72.6-83.5 \%$ of ears $\mathrm{m}^{-2}, 46.6-94.1 \%$ of grains ear ${ }^{-1}$ and $84.5-92.7 \%$ of thousand grain weight data variation. The interaction of all meteorological factors influenced the grain yield by $25.6 \%$ and $40.7 \%$ at $\mathrm{N}_{60-180}$ and split $\mathrm{N}_{90}, \mathrm{~N}_{150}$ levels, respectively.
\end{abstract}

Key words: fertilization, meteorological factors, nitrogen, yield structure.

\section{Introduction}

Grain yield in spring triticale is the result of a number of complex morphological and physiological processes affecting one another and occurring at different growth stages of the vegetation period. It is determined by three major components, namely, number of ears per unit area, number of grains per ear and a thousand grain weight (TGW). Some yield components significantly affect grain yield through effects at different growth stages, from sowing to harvesting. It is therefore necessary to know as much as possible about the relationships among yield, yield components and the meteorological conditions of the growing season. This would allow increasing the productivity of triticale ( $\times$ Tritiosecale Wittm.) and obtaining higher yield. Triticale yield formation has not been widely investigated in terms of contribution of yield components to yield determination, namely under different nitrogen nutrition levels. In cereals, researchers try to explain the relationships between grain yield and its components by using a simple correlation method (Feizienè et al., 2004; Lopez-Bellido et al., 2004; Ali et al., 2010; Waqar-ul-Haq et al., 2010; Sokoto et al., 2012). Subhani and Chowdhry (2000) and Waqar-ul-Haq et al. (2010) indicated positive and significant correlation between wheat grain yield and tillers plant ${ }^{-1}$, ear length, grains ear ${ }^{-1}$ and TGW. Ali et al. (2010) reported positive and significant correlation of spring wheat grain yield with the grains ear ${ }^{-1}$, ear length and TGW. Feiziene et al. (2004) conducted studies with winter wheat and concluded that yield components such as ear length, coefficient of productive tillering and TGW were strongly and significantly associated with grain yield.

Although correlation coefficients are very important to determine yield elements that directly affect grain yield, they are insufficient to define indirect effects of these elements on grain yield. Path analysis is a basic method that enables inferences to be drawn about causal structure of data. Path coefficient is a numerical estimate of the causal relationship between two variables in the path analysis (Kozak, Kang, 2006). The yield components have either a direct or indirect effect on grain yield, or both. Therefore, path analysis can be characterised as an essential means for determination of effects of yield components on grain yield. Garsia del Moral et al. (2003; 2005) have reported that path coefficient analysis showed 
grain yield to be mostly determined by grain weight and the number of ears $\mathrm{m}^{-2}$. Feizienè et al. (2004) suggested that wheat grain yield depended on ear length, TGW and productive tillering. Furthermore, ear length was the dominant factor, determining grain yield. Meteorological conditions are very important because they affect grain yield and its components during the growing season.

The objectives of this study were: i) to evaluate the relationship between spring triticale grain yield and its components under different $\mathrm{N}$ fertilization regimes, ii) to establish the impact of meteorological factors on them iii) to explain the causality of associations between the mentioned parameters through direct and indirect effects.

\section{Materials and methods}

Site and soil properties. A field experiment was set up at the Institute of Agriculture, Lithuanian Research Centre for Agriculture and Forestry in Central Lithuania $\left(55^{\circ} 23^{\prime} 50^{\prime \prime} \mathrm{N}\right.$ and $\left.23^{\circ} 51^{\prime} 40^{\prime \prime} \mathrm{E}\right)$ during the period 2008 2011. The soil of the experimental site is EndocalcariEndohypogleyic Cambisol (CMg- $n$-w-can) (FAO, 1998). The mean soil characteristics (at $0-25 \mathrm{~cm}$ sampling depth) of the experimental plot, determined annually at the beginning of the experiment, were as follows: available $\mathrm{P}_{2} \mathrm{O}_{5}$ 98-168 mg kg-1 (A-L method), available $\mathrm{K}_{2} \mathrm{O} 133-148 \mathrm{mg} \mathrm{kg}^{-1}$ (A-L method), $\mathrm{pH}_{\mathrm{KCl}}$ 5.5-6.7 (potentiometrically). The content of $\mathrm{N}$ min was 33-55 $\mathrm{kg} \mathrm{ha}^{-1}$ in $0-40 \mathrm{~cm}$ soil layer $\left(\mathrm{N}-\mathrm{NO}_{3}-\right.$ ionometrically, $\mathrm{N}-\mathrm{NH}_{4}-$ spectrophotometrically).

Treatments and agronomic management. Spring triticale (cv. 'Nilex') was sown at a density of 4 million viable seeds ha- ${ }^{-1}$. The plot size was $20.4 \mathrm{~m}^{2}$. The crops were fertilized with $66 \mathrm{~kg} \mathrm{ha}^{-1} \mathrm{P}_{2} \mathrm{O}_{5}$ and 130 $\mathrm{kg} \mathrm{ha}^{-1} \mathrm{~K}_{2} \mathrm{O}$ pre-sowing. Nitrogen was applied as basic fertilization in the following treatments: $0\left(\mathrm{~N}_{0}\right), 60\left(\mathrm{~N}_{60}\right)$, $90\left(\mathrm{~N}_{90}\right), 120\left(\mathrm{~N}_{120}\right), 150\left(\mathrm{~N}_{150}\right)$ and $180\left(\mathrm{~N}_{180}\right) \mathrm{kg} \mathrm{ha}^{-1}$; split rates amounted to $\mathrm{N}_{90}\left(\mathrm{~N}_{60}\right.$ before sowing and $\mathrm{N}_{30}$ at stem elongation) and $\mathrm{N}_{150}\left(\mathrm{~N}_{90}\right.$ before sowing, $\mathrm{N}_{30}$ at stem elongation, $\mathrm{N}_{30}$ at end of booting - beginning of heading). Each treatment had four replications. Weed control, diseases and pest management were carried out in accordance with the crop development as required. The number of ears $\mathrm{m}^{-2}$ was determined at maturity from a sample taken from two rows $100 \mathrm{~cm}$ in length from each plot. Grain ear ${ }^{-1}$ was determined on randomly selected 10 main stems for each plot. A thousand grain weight (TGW) was calculated with a seed counter "Contador" ("Pfeuffer", Germany) from four samples of 500 grains per plot. The plots were mechanically harvested at physiological maturity and the yield was expressed at $15 \%$ grain moisture content.

The weather conditions are presented in Figure. Rainfall differed markedly between years. The total amount of rainfall was $170 \mathrm{~mm}$, or $68 \%$ of the long-term mean, and this resulted in dry growth period in 2008. The growing seasons in 2009 and 2011 were wetter and the total rainfall was to 298 and $262 \mathrm{~mm}$, respectively, or was by $19 \%$ and $4 \%$ higher than the long-term mean. 2010 was the wettest year; the rainfall of the growing period totalled $390 \mathrm{~mm}$, or was by $56 \%$ higher, compared to the longterm mean. The mean air temperature in 2008 and 2009 was similar to the long-term mean. In 2010 and 2011, the mean air temperature during the growing season was 0.7 $1.4,0.6-2.4,3.0-4.0$ and $0.6-3.1^{\circ} \mathrm{C}$ above the long-term mean in May, June, July and August, respectively.

Statistical analysis. Analysis of variance was performed using the ANOVA statistical package with two-way factors, $\mathrm{N}$ fertilization and year. Statistical significance was evaluated at the $P \leq 0.05$ and $P \leq 0.01$ probability levels. The combined data of grain yield and its components over the four seasons of the study were analysed by simple correlation, multiple linear regression and path analysis $(\mathrm{n}=16, \mathrm{n}=80$ and $\mathrm{n}=32$, respectively in $\mathrm{N}_{0}$, single $\mathrm{N}_{60-180}$ and split $\mathrm{N}_{90}, \mathrm{~N}_{150}$ levels). A matrix of simple correlation coefficients between grain yield and its components was computed. Multiple linear regression and 3 coefficients of determination $\left(R^{2}\right)$ were estimated for each yield component (Snedecor, Cochran, 1981) in order to evaluate the relative contribution and to develop
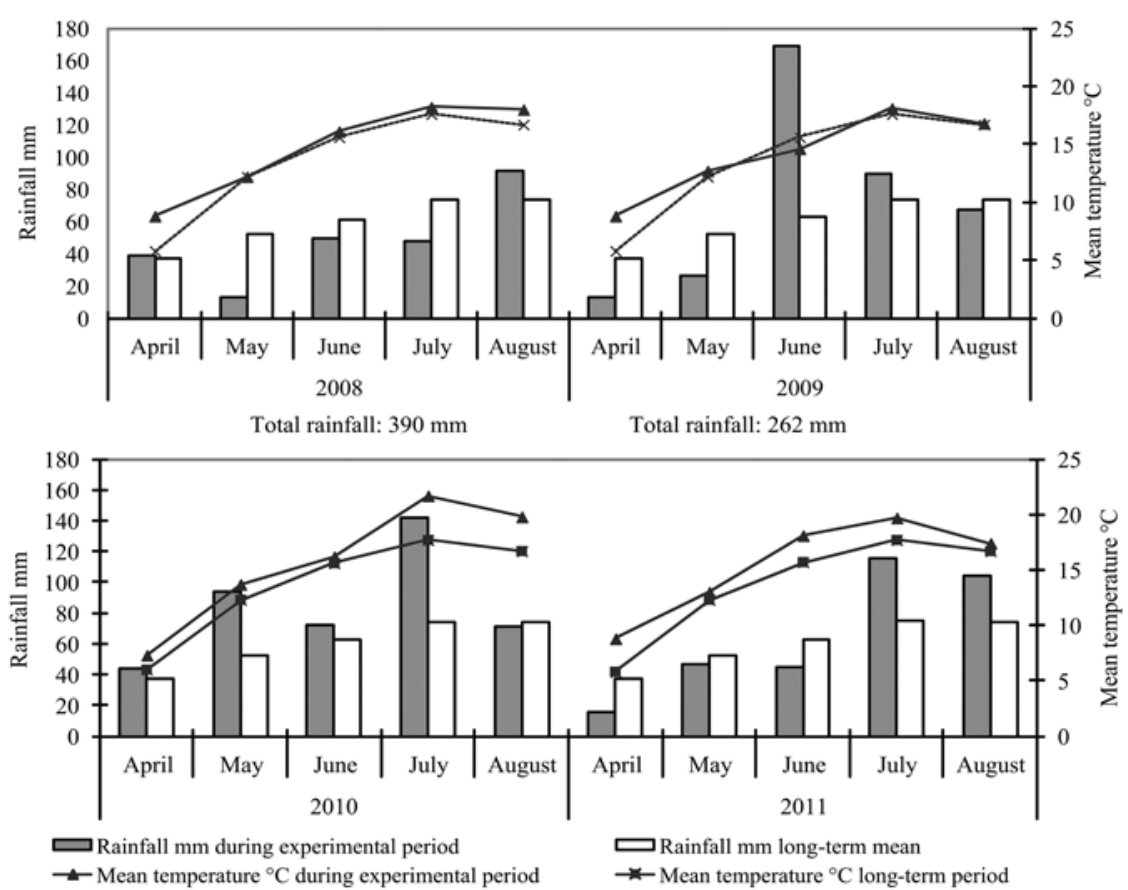

Figure. Monthly mean air temperature and rainfall over the four-year experiment compared with a long-term mean 
the prediction model for grain yield (y) according to the formula: $y=a+b_{1} x_{1}+b_{2} x_{2}+b_{3} x_{3}+\ldots+b_{n} x_{n}$. The multiple linear regression model was also used to assess the correlation between grain yield, its components and meteorological factors. Path coefficient analysis was made on the basis of correlation coefficients taking grain yield as effect and the remaining estimated characters as cause. Direct and indirect effects of component characters on grain yield were worked out using path coefficient analysis (Wright, 1960). Appropriate statistical analysis was done using STAT ENG software from the statistical data processing package SELEKCIJA (Tarakanovas, Raudonius, 2003). Arithmetic mean $(\bar{X})$, standard error $(\mathrm{S} \bar{X})$, minimum and maximum values, coefficient of variation $(\mathrm{CV})$ were calculated.

\section{Results and discussion}

The arithmetic mean, standard error, minimum and maximum values and coefficient of variation for all estimated parameters of spring triticale are provided in Table 1 . The highest variation of values was found at the $\mathrm{N}_{0}$ fertilization level - coefficient of variation $(\mathrm{CV})$ of grain yield was $13.4 \%$, of ear $\mathrm{m}^{-2}$ and grains ear ${ }^{-1} 42.3$ and $16.4 \%$, respectively. The variation of TGW values at the $\mathrm{N}_{0}$ level was the least (CV 5.4\%) compared with single $\mathrm{N}_{60-180}$ fertilization and split $\mathrm{N}_{90}, \mathrm{~N}_{150}$.

Table 1. The statistical indicators of spring triticale grain yield and its components in 2008-2011

\begin{tabular}{|c|c|c|c|c|c|c|}
\hline Variables & Nitrogen $(\mathrm{N})$ level & $\bar{X}$ mean & $\mathrm{s} \bar{x}$ & Min & $\operatorname{Max}$ & $\mathrm{CV}$ \\
\hline \multirow{3}{*}{ Grain yield $\mathrm{Mg} \mathrm{ha}^{-1}$} & $\mathrm{~N}_{0}$ & 3.66 & 0.12 & 2.80 & 4.64 & 13.4 \\
\hline & single $\mathrm{N}_{60-180}$ & 4.85 & 0.06 & 4.00 & 6.35 & 10.3 \\
\hline & split $\mathrm{N}_{90}, \mathrm{~N}_{150}$ & 4.92 & 0.09 & 4.06 & 5.82 & 10.4 \\
\hline \multirow{3}{*}{ Ears $\mathrm{m}^{-2}$} & $\mathrm{~N}_{0}$ & 280 & 29.6 & 84 & 477 & 42.3 \\
\hline & single $\mathrm{N}_{60-180}$ & 359 & 14.9 & 113 & 644 & 37.2 \\
\hline & split $\mathrm{N}_{90}, \mathrm{~N}_{150}$ & 377 & 24.8 & 133 & 584 & 37.3 \\
\hline \multirow{3}{*}{ Grains ear ${ }^{-1}$} & $\mathrm{~N}_{0}$ & 44 & 1.8 & 31 & 52 & 16.4 \\
\hline & single $\mathrm{N}_{60-180}$ & 48 & 0.8 & 36 & 64 & 14.5 \\
\hline & split $\mathrm{N}_{90}, \mathrm{~N}_{150}$ & 48 & 0.9 & 40 & 59 & 10.2 \\
\hline \multirow{3}{*}{ Thousand grain weight $g$} & $\mathrm{~N}_{0}$ & 39.2 & 0.53 & 36.0 & 43.3 & 5.4 \\
\hline & single $\mathrm{N}_{60-180}$ & 38.5 & 0.29 & 32.7 & 43.2 & 6.7 \\
\hline & split $\mathrm{N}_{90}, \mathrm{~N}_{150}$ & 38.1 & 0.41 & 33.2 & 41.2 & 6.0 \\
\hline
\end{tabular}

$\mathrm{S} \bar{X}-$ standard error, $\mathrm{CV}$ - coefficient of variation

The analysis of variance showed that the effect of $\mathrm{N}$ fertilization $(\mathrm{N})$, year $(\mathrm{Y})$ and their interaction $(\mathrm{Y} \times$ $\mathrm{N})$ on grain yield and its components were statistically significant $(P \leq 0.05$ and $P \leq 0.01)$ with two exceptions in the case of productivity per ear (Table 2 ).

Table 2. Analyses of variance for effects of year, nitrogen (N) fertilization on grain yield and its components of spring triticale crop in 2008-2011

\begin{tabular}{lccccc}
\hline \multicolumn{1}{c}{ Source } & DF $\begin{array}{c}\text { Grain yield } \\
\mathrm{Mg} \mathrm{ha}^{-1}\end{array}$ & $\begin{array}{c}\text { Ears } \\
\mathrm{m}^{-2}\end{array}$ & $\begin{array}{c}\text { Grains } \\
\text { ear }^{-1}\end{array}$ & $\begin{array}{c}\text { TGW } \\
\mathrm{g}\end{array}$ \\
\hline Year (Y) & 3 & $17.97^{* *}$ & $20.62^{* *}$ & $28.17^{* *}$ & $293.12^{* *}$ \\
$\mathrm{~N}$ fertilization (N) & 7 & $27.71^{* *}$ & $6.09^{* *}$ & $2.22^{*}$ & $3.7^{* *}$ \\
$\mathrm{Y} \times \mathrm{N}$ & 21 & $2.32^{* *}$ & $1.83^{*}$ & $1.95^{*}$ & $2.93^{* *}$ \\
\hline
\end{tabular}

$\mathrm{DF}$ - degree of freedom; ${ }^{*}, * *$ - significant at the $P \leq 0.05$ and $P \leq 0.01$ probability level, respectively; ns - not significant, TGW - thousand grain weight

The relationship between grain yield and yield components. The correlation among the investigated indices is presented in Table 3. The strength of relationship between parameters was unequal at the different $\mathrm{N}$ levels. Grain yield correlation with yield components at $\mathrm{N}_{0}$ level was insignificant, whereas grain yield correlation with the ears $\mathrm{m}^{-2}\left(r=0.327^{* *}\right)$ and TGW $\left(r=0.410^{* *}\right)$ under single $\mathrm{N}_{60-180}$ fertilization was significant and positive. Grain yield under split $\mathrm{N}_{90}$ and $\mathrm{N}_{150}$ positively and significantly correlated with the ears $\mathrm{m}^{-2}\left(r=0.477^{* *}\right)$. However, the grain yield relation with grains ear $^{-1}\left(r=-0.511^{* *}\right)$ was significant and negative. TGW correlation with grain yield at split $\mathrm{N}_{90}$ and $\mathrm{N}_{15}$ treatments was significant. The ears $\mathrm{m}^{-2}$ negatively and significantly $(P \leq 0.01)$ correlated with the grains ear ${ }^{1}$ at all $\mathrm{N}$ regimes, i.e. the higher the number of ears per square meter, the lower the number of grains per ear. The relationship between the ears $\mathrm{m}^{-2}$ and TGW was positive and significant $(P \leq 0.01)$ under the both single $\mathrm{N}_{60-180}$ and split $\mathrm{N}_{90}, \mathrm{~N}_{150}$ fertilization. The ears $\mathrm{m}^{-2}$ and grains ear ${ }^{-1}$ did not significantly correlate with $\mathrm{TGW}$ at $\mathrm{N}_{0}$ level. The grains ear ${ }^{-1}$ negatively and significantly correlated with TGW under single $\mathrm{N}_{60-180}(P \leq 0.05)$ and split $\mathrm{N}_{90}, \mathrm{~N}_{150}$ fertilization $(P \leq 0.01)$. In summary, we suppose that the yield and yield components correlated weaker at $\mathrm{N}_{0}$ level than under single $\mathrm{N}_{60-180}$ and split $\mathrm{N}_{90}, \mathrm{~N}_{150}$ fertilization. The relation between yield and yield components indicated that ears $\mathrm{m}^{-2}$ and grains ear ${ }^{-1}$ produced the greatest influence on grain yield. Kozak et al. (2007) found that grain yield is usually positively correlated with all its components; the spikes $\mathrm{m}^{-2}$ is not correlated with grain spike ${ }^{-1}$; spikes $\mathrm{m}^{-2}$ is not or is negatively correlated with grain weight; and there is no significant correlation between the grain spike $^{-1}$ and grain weight, or the correlation is positive. Garcia del Moral et al. (2003) also found the relationship between grain and its components and path coefficients analysis helped to establish the causality of the relation.

The data presented in Table 4 show regression coefficients $\left(\mathrm{b}_{1}, \mathrm{~b}_{2}, \mathrm{~b}_{3}\right)$ of the yield components $\left(\mathrm{x}_{1}, \mathrm{x}_{2}, \mathrm{x}_{3}\right)$ and the significance of the relationship between the grain yield (y) and its components at the different $\mathrm{N}$ levels. According to the multiple linear regression model $(y=a$ $\left.+b_{1} x_{1}+b_{2} x_{2}+b_{3} x_{3}+\ldots+b_{n} x_{n}\right)$, significant relationship between grain yield and yield components was in the both fertilized treatments $\left(R=0.415^{* *}\right.$ and $R=0.532^{*}$, respectively). It was found that the interaction of grain yield components influenced the grain yield by $17.2 \%$ 
Table 3. The correlation matrix between spring triticale grain yield and yield components for 2008-2011

\begin{tabular}{|c|c|c|c|c|}
\hline Nitrogen (N) level & & $\begin{array}{c}\text { Ears } \\
\mathrm{m}^{-2}\end{array}$ & $\begin{array}{c}\text { Grains } \\
\text { ear }^{-1}\end{array}$ & $\begin{array}{c}\text { Thousand grain } \\
\text { weight }\end{array}$ \\
\hline \multirow{3}{*}{$\mathrm{N}_{0}$} & grain yield & -0.065 & 0.090 & 0.018 \\
\hline & ears $\mathrm{m}^{-2}$ & - & $-0.757 * *$ & 0.416 \\
\hline & grains ear $^{-1}$ & - & - & 0.034 \\
\hline \multirow{3}{*}{ Single $N_{60-180}$} & grain yield & $0.327 * *$ & -0.170 & $0.410 * *$ \\
\hline & ears $\mathrm{m}^{-2}$ & - & $-0.378 * *$ & $0.747 * *$ \\
\hline & grains ear $^{-1}$ & - & - & $-0.284 *$ \\
\hline \multirow{3}{*}{ Split $\mathrm{N}_{90}, \mathrm{~N}_{150}$} & grain yield & $0.477 * *$ & $-0.511 * *$ & 0.336 \\
\hline & ears $\mathrm{m}^{-2}$ & - & $-0.764 * *$ & $0.796 * *$ \\
\hline & grains ear-1 & - & - & $-0.595^{* *}$ \\
\hline
\end{tabular}

*, ** - correlation is significant at $P \leq 0.05$ and $P \leq 0.01$, respectively

Table 4. The regression coefficients $\left(\mathrm{b}_{1}, \mathrm{~b}_{2}, \mathrm{~b}_{3}\right)$ of the estimated variables $\left(\mathrm{x}_{1}, \mathrm{x}_{2}, \mathrm{x}_{3}\right)$ in spring triticale grain yield (y) by the multiple linear regression analysis and correlation coefficient $(R)$

\begin{tabular}{|c|c|c|c|c|c|c|}
\hline \multirow{2}{*}{ Nitrogen $(\mathrm{N})$ level } & \multirow{2}{*}{$y$-intercept (a) } & \multicolumn{3}{|c|}{ Coefficient of regression equation (b) } & \multirow{2}{*}{$R$} & \multirow{2}{*}{$F_{\text {act. }}$} \\
\hline & & $\mathrm{b}_{1}$ & $b_{2}$ & $b_{3}$ & & \\
\hline $\mathrm{N}_{0}$ & 3.24 & 0.0001 & 0.005 & 0.005 & 0.092 & 0.03 \\
\hline Single $\mathrm{N}_{60-180}$ & 2.22 & 0.0001 & 0.072 & -0.004 & 0.415 & $5.25 * *$ \\
\hline Split $\mathrm{N}_{90}, \mathrm{~N}_{150}$ & 7.17 & 0.001 & -0.023 & -0.037 & 0.532 & $3.69^{*}$ \\
\hline
\end{tabular}

Notes. Multi reqression equation $\mathrm{y}=\mathrm{a}+\mathrm{b}_{1} \mathrm{x}_{1}+\mathrm{b}_{2} \mathrm{x}_{2}+\mathrm{b}_{3} \mathrm{x}_{3} ; \mathrm{x}_{1}-$ ears $\mathrm{m}^{-2}, \mathrm{x}_{2}-$ thousand grain weight, $\mathrm{x}_{3}-$ grains ear $^{-1}$ * $^{* *}-$ correlation is significant at $P \leq 0.05$ and $P \leq 0.01$, respectively.

and $28.3 \%$ in the treatments fertilized with single $\mathrm{N}_{60-180}$ and split $\mathrm{N}_{90}, \mathrm{~N}_{150}$, respectively, whereas at $\mathrm{N}_{0}$ level the grain yield relation with all other yield components was insignificant.

Direct and indirect effects of yield components on grain yield. Path analysis showed direct and indirect effect of causal variables on effect variables. In this method, the correlation coefficient between two traits is separated into the components which measure the direct and indirect effects (Peymaninia et al., 2012). The path coefficients were partitioned into direct and indirect effects at different $\mathrm{N}$ levels (Table 5). Distribution of correlation coefficients shows the impact of all meteorological factors on the formation process of yield and its structural elements. The sum of entire path coefficients corresponds to the correlation coefficient of individual meteorological factors.

At the $\mathrm{N}_{0}$ level, the direct positive effects of TGW $($ Pxy $=0.021)$ and grains ear $^{-1}(\mathrm{Pxy}=0.079)$ on grain yield were negligible. The ears $\mathrm{m}^{-2}$ revealed the lowest negative effect on grain yield $(P x y=-0.014)$. In this unfertilized treatment, TGW and grains ear-1 had the dominant effects. Namely these factors determined spring triticale grain yield at $\mathrm{N}_{0}$ level.

At $\mathrm{N}_{60-180}$ level, the direct and dominant effect on grain yield was shown by TGW $(P x y=0.376)$ and it was positive. This means that namely TGW as a dominant factor determined yield of spring triticale. The direct effect of the ears $\mathrm{m}^{-2}(\mathrm{Pxy}=0.026)$ on yield was positive but tenuous. The grains ear ${ }^{-1}$ had low direct negative effect on grain yield (Pxy $=-0.054)$.

At split $\mathrm{N}_{90}$ and $\mathrm{N}_{150}$ level, direct contributions of grain yield components to grain yield ranged from Pxy $=0.293$ in the ears $\mathrm{m}^{-2}$ to Pxy $=-0.350$ in the grains ear ${ }^{-1}$. The direct effect of TGW (Pxy $=-0.106$ ) on grain yield was negative and weak. However, this negative effect was offset by the positive indirect and dominant effect via the grains ear ${ }^{-1}\left(\mathrm{rx}_{2} \mathrm{x}_{3} \mathrm{Px}_{2} \mathrm{y}=0.208\right)$ and ears $\mathrm{m}^{-2}\left(\mathrm{rx}_{2} \mathrm{x}_{4} \mathrm{Px}_{2} \mathrm{y}=\right.$ 0.233 ). These results are in agreement with those of Ashfaq et al. (2003). Negative direct effect of TGW on grain yield also was found in bread wheat, while positive and maximum indirect effect was via other yield components (Subhani, Chowdhry, 2000). In our study, the grains ear ${ }^{-1}$ demonstrated the direct and dominant negative effect on grain yield ( $\mathrm{Pxy}=-0.350)$, whereas negative indirect effect of the ears $\mathrm{m}^{-2}\left(\mathrm{rx}_{3} \mathrm{x}_{4} \mathrm{Px}_{3} \mathrm{y}=-0.224\right)$ additionally enhanced the negative impact of grains ear ${ }^{-1}$ on grain yield and sum of entire path produced final result, i.e. correlation coefficient $\left(r=-0.511^{* *}\right)$. Contrary data has been obtained in the experiment with wheat, where direct effect of the grains ear $^{-1}$ on grain yield was positive (Ashfaq et al., 2003). However, our observations were consistent with Leilah and Al-Khateeb (2005) investigations on wheat plant yield components, were they found that the number of ears $\mathrm{m}^{-2}(\mathrm{Pxy}=0.118)$, grains ear $^{-1}(\mathrm{Pxy}=0.018)$ and TGW (Pxy $=-0.005)$ had low direct effects on grain

Table 5. Effects of yield components on grain yield of spring triticale grown at different nitrogen (N) regimes

\begin{tabular}{|c|c|c|c|c|c|c|}
\hline & \multirow{2}{*}{$\mathrm{N}$ level } & \multirow{2}{*}{ Variables } & \multicolumn{3}{|c|}{ Path coefficient } & \multirow{2}{*}{$1(r \mathrm{Y})$} \\
\hline & & & 2 & 3 & 4 & \\
\hline \multirow{9}{*}{$\begin{array}{c}\text { Grain yield } \\
\text { (Y) }\end{array}$} & \multirow{3}{*}{$\mathrm{N}_{0}$} & TGW (2) & 0.021 & 0.003 & -0.006 & 0.018 \\
\hline & & grains ear ${ }^{-1}(3)$ & 0.0007 & 0.079 & 0.011 & 0.090 \\
\hline & & ears $m^{-2}(4)$ & 0.009 & -0.059 & -0.014 & -0.065 \\
\hline & \multirow{3}{*}{ Single $\mathrm{N}_{60-180}$} & TGW (2) & 0.376 & 0.015 & 0.020 & $0.410 * *$ \\
\hline & & grains ear-1 (3) & -0.107 & -0.054 & -0.010 & -0.170 \\
\hline & & ears $\mathrm{m}^{-2}(4)$ & 0.280 & 0.020 & 0.026 & $0.327 * *$ \\
\hline & \multirow{3}{*}{ Split $\mathrm{N}_{90}, \mathrm{~N}_{150}$} & TGW (2) & -0.106 & 0.208 & 0.233 & 0.336 \\
\hline & & grains ear ${ }^{-1}(3)$ & 0.063 & -0.350 & -0.224 & $-0.511 * *$ \\
\hline & & ears $\mathrm{m}^{-2}(4)$ & -0.084 & 0.268 & 0.293 & $0.477 * *$ \\
\hline
\end{tabular}

TGW - thousand grain weight; *,** - correlation is significant at $P \leq 0.05$ and $P \leq 0.01$, respectively; numbers in bold - direct effect, numbers in Italic - dominant effect 
yield. Through correlation and path coefficient analysis, Feiziene et al. (2004) observed in winter wheat that grain yield positively and strongly correlated (the sum of entire path) with productive tillering, ear length and TGW; however, the grains ear ${ }^{-1}$ and TGW direct effect was weak. Okuyama et al. (2004) have also reported that path analysis revealed positive direct effect and moderate correlation of ears $\mathrm{m}^{-2}$ and grains ear-1 with grain yield. A more detailed study of the relations obtained by path analysis showed that the interrelation between grain yield and its components is somewhat different from that presented in the simple analysis of correlation.

The relationship between grain yield, yield components and meteorological factors. The simple correlation coefficients revealed that the grain yield positively and significantly $(P \leq 0.01)$ correlated with growing degree days (GDD) $>10^{\circ} \mathrm{C}$ at $\mathrm{N}_{60-180}(r=0.479)$ and split $\mathrm{N}_{90}$ and $\mathrm{N}_{150}$ level $(r=0.591)$ (Table 6). The correlation between grain yield and GDD $>10^{\circ} \mathrm{C}$ at $\mathrm{N}_{0}$ level was weak and insignificant, the same as between grain yield and other meteorological factors at all $\mathrm{N}$ regimes. The ears $\mathrm{m}^{-2}$ negatively correlated with rainfall and air humidity $(\mathrm{AH})$ but the correlation was significant $(P \leq 0.01)$ only in fertilized treatments, whereas at $\mathrm{N}_{0}$ level the relationship was weak and insignificant. The positive correlation was detected between the ears $\mathrm{m}^{-2}$ and GDD $>10^{\circ} \mathrm{C}(P \leq 0.05)$ at the single $\mathrm{N}_{60-180}$ and at split $\mathrm{N}_{90}$, ${ }_{150}$ levels; meanwhile, the relationship was weak and insignificant at $\mathrm{N}_{0}$ level. The strongest significant $(P \leq 0.01)$ correlation between the ears $\mathrm{m}^{-2}$ and sunshine duration (SD) was detected at all $\mathrm{N}$ levels. The grains ear ${ }^{-1}$ correlated weakly and insignificantly with the amount of rainfall and $\mathrm{AH}$, except for at single $\mathrm{N}_{60-180}$ fertilization level, when the correlation was weak but significant $(P \leq 0.05)$. The negative and significant correlation between the grains ear ${ }^{-1}$ and GDD $>10^{\circ} \mathrm{C}$ was found at $\mathrm{N}_{0}$ and split $\mathrm{N}_{90}, \mathrm{~N}_{150}$ levels $(P \leq 0.01)$. The relationship of the grains ear ${ }^{-1}$ with SD was negative at all $\mathrm{N}$ levels, but significant $(P \leq 0.01)$ only in fertilized treatments. TGW inversely significantly correlated with the amount of rainfall and $\mathrm{AH}(P \leq 0.01)$ at all $\mathrm{N}$ levels. The positive significant correlation was detected between TGW and GDD $>10^{\circ} \mathrm{C}$, except for the relationship at $\mathrm{N}_{0}$ level. TGW strongly, positively and significantly $(P \leq 0.01)$ correlated with SD at all $\mathrm{N}$ levels. Yield components and grain quality depend not only on the fertilization strategy, but also on the weather conditions (Garsia del Moral et al., 2005; Pecio, 2010; Villegas et al., 2010). The interaction between the amount of rainfall, GDD > $5^{\circ} \mathrm{C}$, GDD $>10^{\circ} \mathrm{C}$ and $\mathrm{SD}$ in relation to plant growth stage predetermined the variation of yield and yield increase by $85-94 \%$ (Janušauskaite, 2008). The weather conditions of the growing season can affect $44-55 \%$ of yield variation (Erekul, Köhn, 2006). Triticale is the most sensitive to rainless conditions during the grain filling, and drought stress accounted for $7-50 \%$ of grain yield variation (Royo et al., 2000). In the study of Alaru et al. (2003), it was found that meteorological factors had a greater impact on the variations of triticale grain yield than nitrogen fertilization. The findings of Ugarte et al. (2007) revealed that temperature during booting-preanthesis affected two major yield components - grain number $\mathrm{m}^{-2}$ and grain weight. Garcia del Moral et al. (2003) observed that the relation between grain yield and its components differed under different temperature-moisture regime combinations, but grain yield was greater in the cooler than in warmer environment, a consequence of more ears $\mathrm{m}^{-2}$, heavier grain and a longer vegetative period and grain filling period. The results of Pecio (2010) confirmed the relationships between the moisture conditions during the vegetation period and grain yield. The variations in grain yield due to the changes in water availability were associated more with a change in grains per unit area than in grain weight (Estrada-Campuzano et al., 2012).

Table 6. The correlation between spring triticale grain yield, yield components and meteorological factors

\begin{tabular}{|c|c|c|c|c|c|}
\hline \multirow{2}{*}{ Variables } & \multirow{2}{*}{ Nitrogen $(\mathrm{N})$ level } & \multicolumn{4}{|c|}{ Correlation coefficients } \\
\hline & & rainfall $\mathrm{mm}$ & $\mathrm{GDD}>10^{\circ} \mathrm{C}$ & SD h & AH \% \\
\hline \multirow{3}{*}{ Grain yield } & $\mathrm{N}_{0}$ & 0.066 & 0.056 & -0.225 & 0.198 \\
\hline & single $N_{60-180}$ & -0.158 & $0.479 * *$ & 0.197 & -0.12 \\
\hline & split $\mathrm{N}_{90}, \mathrm{~N}_{150}$ & -0.131 & $0.591 * *$ & 0.234 & 0.020 \\
\hline \multirow{3}{*}{ Ears $m^{-2}$} & $\mathrm{~N}_{0}$ & -0.207 & 0.437 & $0.725 * *$ & -0.393 \\
\hline & single $\mathrm{N}_{60-180}$ & $-0.542 * *$ & $0.227 *$ & $0.839 * *$ & $-0.697 * *$ \\
\hline & split $\mathrm{N}_{90}, \mathrm{~N}_{150}$ & $-0.530 * *$ & $0.427 *$ & $0.825 * *$ & $-0.605 * *$ \\
\hline \multirow{3}{*}{ Grains ear ${ }^{-1}$} & $\mathrm{~N}_{0}$ & -0.113 & $-0.629 * *$ & -0.420 & -0.022 \\
\hline & single $\mathrm{N}_{60-180}$ & -0.008 & -0.203 & $-0.486 * *$ & $0.233^{*}$ \\
\hline & split $\mathrm{N}_{90}, \mathrm{~N}_{150}$ & 0.320 & $-0.511 * *$ & $-0.620 * *$ & 0.346 \\
\hline \multirow{3}{*}{ Thousand grain weight } & $\mathrm{N}_{0}$ & $-0.858 * *$ & 0.055 & $0.774 * *$ & $-0.862 * *$ \\
\hline & single $\mathrm{N}_{60-180}$ & $-0.790 * *$ & $0.425 * *$ & $0.789 * *$ & $-0.703 * *$ \\
\hline & split $\mathrm{N}_{90}, \mathrm{~N}_{150}$ & $-0.840 * *$ & $0.418 *$ & $0.84 * *$ & $-0.756 * *$ \\
\hline
\end{tabular}

Notes. GDD - the baseline temperature used for growing degree days computation was $10^{\circ} \mathrm{C}, \mathrm{SD}$ - sunshine duration, $\mathrm{AH}-$ air humidity. ${ }^{*}, * *$ correlation is significant at $P \leq 0.05$ and $P \leq 0.01$, respectively.

Multiple regression analysis is a good tool to study the individual contribution of many traits (independent traits) to the performance of a trait (dependent trait) (Felenji, Ahmadizadeh, 2011). The multiple linear regression model $\left(\mathrm{y}=\mathrm{a}+\mathrm{b}_{1} \mathrm{x}_{1}+\mathrm{b}_{2} \mathrm{x}_{2}+\mathrm{b}_{3} \mathrm{x}_{3}+\mathrm{b}_{4} \mathrm{x}_{4}\right)$ showed that grain yield and yield components were intensely and significantly $(P \leq 0.01)$ influenced by the meteorological factors (Table 7). Meteorological factors during the study period from sowing to harvest varied within the range: $171 \mathrm{~mm} \leq$ rainfall $\left(\mathrm{x}_{1}\right) \leq 390 \mathrm{~mm}, 1742{ }^{\circ} \mathrm{C} \leq$ GDD $>$ $10^{\circ} \mathrm{C}\left(\mathrm{x}_{2}\right) \leq 1907^{\circ} \mathrm{C}, 833 \mathrm{~h} \leq \mathrm{SD}\left(\mathrm{x}_{3}\right) \leq 1158 \mathrm{~h}, 64,2 \% \leq$ $\mathrm{AH}\left(\mathrm{x}_{4}\right) \leq 75.6 \%$. The interaction of all meteorological factors influenced the grain yield by $25.6 \%$ and $40.7 \%$ at $\mathrm{N}_{60-180}$ and split $\mathrm{N}_{90}, \mathrm{~N}_{150}$ levels, respectively. Meanwhile, the least and insignificant impact (only 6.3\%) of the weather conditions was on the grain yield at $\mathrm{N}_{0}$ level. In the previous experiments with winter triticale it was found that the meteorological factors determined grain yield by $88 \%$ and by $98 \%$ under starter nitrogen applied and under additional $\mathrm{N}$ fertilization, respectively (Janušauskaitè, 2008). Obuchowski et al. (2010) also indicated a noticeable effect of the weather conditions on triticale yield. In our study, meteorological conditions caused $72.6-83.5 \%$ of ears $\mathrm{m}^{-2}, 46.6-94.1 \%$ of grains ear $^{-1}$ and $84.5-92.7 \%$ of TGW data variation.

Direct and indirect effects of meteorological factors on grain yield and yield components. Direct effects of meteorological factors on grain yield ranged 
Table 7. The correlation coefficient $(R)$ of the multiple correlation between spring triticale grain yield, yield components and meteorological factors and regression coefficients of the multiple linear regression analysis

\begin{tabular}{|c|c|c|c|c|c|c|c|}
\hline \multirow{2}{*}{$\begin{array}{l}\text { Variables } \\
\text { (y) }\end{array}$} & \multirow{2}{*}{$\begin{array}{c}\text { Nitrogen }(\mathrm{N}) \\
\text { level }\end{array}$} & \multirow{2}{*}{$\stackrel{\mathrm{y}-}{\text { intercept (a) }}$} & \multicolumn{4}{|c|}{ Coefficient of regression equation (b) } & \multirow{2}{*}{$R$} \\
\hline & & & $b_{1}$ & $\mathrm{~b}_{2}$ & $b_{3}$ & $\mathrm{~b}_{4}$ & \\
\hline \multirow{3}{*}{$\begin{array}{l}\text { Grain yield } \\
\left(\mathrm{y}_{1}\right)\end{array}$} & $\mathrm{N}_{0}$ & 2.84 & -0.002 & -0.0007 & -0.0002 & 0.04 & 0.252 \\
\hline & single $\mathrm{N}_{60-180}$ & -4.91 & -0.001 & 0.003 & 0.002 & 0.049 & $0.506^{* *}$ \\
\hline & split $\mathrm{N}_{90}, \mathrm{~N}_{150}$ & -6.69 & 0.001 & 0.005 & 0.002 & 0.018 & $0.638^{* *}$ \\
\hline \multirow{3}{*}{$\begin{array}{c}\text { Ear m }{ }^{-2} \\
\left(y_{2}\right)\end{array}$} & $\mathrm{N}_{0}$ & -2083.58 & 1.310 & 1.284 & 0.593 & -13.741 & $0.914 * *$ \\
\hline & single $\mathrm{N}_{60-180}$ & -1386.25 & -0.157 & 0.125 & 1.004 & 7.209 & $0.852 * *$ \\
\hline & split $\mathrm{N}_{90}, \mathrm{~N}_{150}$ & -2015.78 & 0.328 & 0.987 & 0.798 & -4.753 & $0.898 * *$ \\
\hline \multirow{3}{*}{$\begin{array}{c}\text { Thousand } \\
\text { grain weight } \\
\left(\mathrm{y}_{3}\right)\end{array}$} & $\mathrm{N}_{0}$ & 39.51 & -0.026 & -0.011 & 0.011 & 0.233 & $0.919 * *$ \\
\hline & single $\mathrm{N}_{60-180}$ & 5.29 & -0.019 & 0.008 & 0.013 & 0.148 & $0.920 * *$ \\
\hline & split $\mathrm{N}_{90}, \mathrm{~N}_{150}$ & 3.87 & -0.024 & 0.001 & 0.016 & 0.323 & $0.963 * *$ \\
\hline \multirow{3}{*}{$\begin{array}{l}\text { Grains ear }{ }^{-1} \\
\left(\mathrm{y}_{4}\right)\end{array}$} & $\mathrm{N}_{0}$ & 202.03 & -0.149 & -0.150 & 0.001 & 2.214 & $0.970 * *$ \\
\hline & single $\mathrm{N}_{60-180}$ & 193.74 & -0.038 & -0.008 & -0.062 & -0.799 & $0.683^{* *}$ \\
\hline & split $\mathrm{N}_{90}, \mathrm{~N}_{150}$ & 114.45 & -0.054 & -0.076 & 0.001 & 1.245 & $0.793 * *$ \\
\hline
\end{tabular}

Notes. Multi regression equation $\mathrm{y}=\mathrm{a}+\mathrm{b}_{1} \mathrm{x}_{1}+\mathrm{b}_{2} \mathrm{x}_{2}+\mathrm{b}_{3} \mathrm{x}_{3}+\mathrm{b}_{4} \mathrm{x}_{4} ; \mathrm{x}_{1}-$ rainfall, $\mathrm{x}_{2}-\mathrm{GDD}>10^{\circ} \mathrm{C}$ (the baseline temperature used for growing degree days computation was $10^{\circ} \mathrm{C}$ ), $\mathrm{x}_{3}-\mathrm{SD}$ (sunshine duration), $\mathrm{x}_{4}-\mathrm{AH}$ (air humidity). *, ** - correlation is significant at $P \leq 0.05$ and $P \leq 0.01$, respectively.

Table 8. The entire path of relationships between spring triticale grain yield, its components and meteorological factors

\begin{tabular}{|c|c|c|c|c|c|c|c|}
\hline \multirow{2}{*}{$\begin{array}{c}\text { Variables } \\
(\mathrm{Y}, 1)\end{array}$} & \multirow{2}{*}{$\begin{array}{c}\text { Nitrogen }(\mathrm{N}) \\
\text { level }\end{array}$} & & \multicolumn{4}{|c|}{ Path coefficient } & \multirow{2}{*}{$1(r \mathrm{Y})$} \\
\hline & & & 2 & 3 & 4 & 5 & \\
\hline \multirow{12}{*}{ Grain yield } & \multirow{4}{*}{$\mathrm{N}_{0}$} & rainfall (2) & -0.273 & 0.020 & 0.036 & 0.282 & 0.066 \\
\hline & & $\mathrm{GDD}>10^{\circ} \mathrm{C}$ & 0.066 & -0.086 & -0.006 & 0.081 & 0.056 \\
\hline & & $\mathrm{SD}(4)$ & 0.172 & -0.008 & -0.058 & -0.331 & -0.225 \\
\hline & & AH (5) & -0.207 & -0.019 & 0.051 & 0.372 & 0.198 \\
\hline & \multirow{4}{*}{$\begin{array}{l}\text { single } \\
\mathrm{N}_{60-180}\end{array}$} & rainfall (2) & -0.109 & -0.075 & -0.312 & 0.338 & -0.158 \\
\hline & & $\mathrm{GDD}>10^{\circ} \mathrm{C}$ & 0.026 & 0.307 & 0.049 & 0.097 & $0.479 * *$ \\
\hline & & $\mathrm{SD}(4)$ & 0.069 & 0.030 & 0.494 & -0.397 & 0.197 \\
\hline & & AH (5) & -0.083 & 0.067 & -0.440 & 0.445 & -0.012 \\
\hline & \multirow{4}{*}{$\begin{array}{l}\text { split } \\
\mathrm{N}_{90}, \mathrm{~N}_{150}\end{array}$} & rainfall (2) & 0.145 & -0.134 & -0.258 & 0.117 & -0.131 \\
\hline & & $\mathrm{GDD}>10^{\circ} \mathrm{C}$ & 0.035 & 0.553 & 0.040 & 0.033 & $0.591 * *$ \\
\hline & & $\mathrm{SD}(4)$ & -0.091 & 0.055 & 0.408 & -0.137 & 0.234 \\
\hline & & $\mathrm{AH}(5)$ & 0.110 & 0.120 & -0.364 & 0.154 & 0.020 \\
\hline \multirow{12}{*}{ Ears $\mathrm{m}^{-2}$} & \multirow{4}{*}{$\mathrm{N}_{0}$} & rainfall (2) & 0.792 & -0.164 & -0.433 & -0.402 & -0.207 \\
\hline & & $\mathrm{GDD}>10^{\circ} \mathrm{C}$ & -0.193 & 0.677 & 0.068 & -0.115 & 0.437 \\
\hline & & $\mathrm{SD}(4)$ & -0.500 & 0.067 & 0.686 & 0.472 & $0.724 * *$ \\
\hline & & $\mathrm{AH}(5)$ & 0.601 & 0.147 & -0.611 & -0.530 & 0.393 \\
\hline & \multirow{4}{*}{$\begin{array}{l}\text { single } \\
\mathrm{N}_{60-180}\end{array}$} & rainfall (2) & $-\mathbf{0 . 0 8 7}$ & -0.013 & -0.634 & 0.192 & $-0.542 * *$ \\
\hline & & $\mathrm{GDD}>10^{\circ} \mathrm{C}$ & 0.021 & 0.052 & 0.099 & 0.055 & $0.227 *$ \\
\hline & & SD (4) & 0.055 & 0.005 & 1.004 & -0.225 & $0.839 * *$ \\
\hline & & AH (5) & -0.066 & 0.011 & -0.895 & 0.253 & $-0.697 * *$ \\
\hline & \multirow{4}{*}{$\mathrm{N}_{90}^{\text {split }}, \mathrm{N}_{150}$} & rainfall (2) & 0.162 & -0.103 & -0.474 & -0.114 & $-0.530 * *$ \\
\hline & & $\mathrm{GDD}>10^{\circ} \mathrm{C}$ & -0.039 & 0.425 & 0.074 & -0.033 & $0.427 *$ \\
\hline & & $\operatorname{SD}(4)$ & -0.102 & 0.042 & 0.751 & 0.134 & $0.825^{* *}$ \\
\hline & & $\mathrm{AH}(5)$ & 0.123 & 0.092 & -0.670 & -0.151 & $-0.605 * *$ \\
\hline \multirow{12}{*}{ Grains ear $^{-1}$} & \multirow{4}{*}{$\mathrm{N}_{0}$} & rainfall (2) & -1.473 & 0.314 & -0.014 & 1.060 & -0.113 \\
\hline & & $\mathrm{GDD}>10^{\circ} \mathrm{C}$ & 0.358 & -1.293 & 0.002 & 0.303 & $-0.629 * *$ \\
\hline & & $\mathrm{SD}(4)$ & 0.930 & -0.128 & 0.023 & -1.245 & -0.420 \\
\hline & & $\mathrm{AH}(5)$ & -1.118 & -0.281 & -0.020 & 1.397 & -0.022 \\
\hline & \multirow{4}{*}{$\begin{array}{l}\text { single } \\
\mathrm{N}_{60-180}\end{array}$} & rainfall (2) & -0.363 & 0.014 & 0.753 & -0.411 & -0.008 \\
\hline & & $\mathrm{GDD}>10^{\circ} \mathrm{C}$ & 0.088 & -0.056 & -0.118 & -0.117 & -0.203 \\
\hline & & $\mathrm{SD}(4)$ & 0.229 & -0.006 & -1.192 & 0.483 & $-0.486 * *$ \\
\hline & & AH (5) & -0.276 & -0.012 & 1.063 & -0.542 & $0.233^{*}$ \\
\hline & \multirow{4}{*}{$\begin{array}{l}\text { split } \\
\mathrm{N}_{90}, \mathrm{~N}_{150}\end{array}$} & rainfall (2) & -0.772 & 0.230 & 0.001 & 0.861 & 0.320 \\
\hline & & $\mathrm{GDD}>10^{\circ} \mathrm{C}$ & 0.188 & -0.945 & -0.001 & -0.247 & $-0.511 * *$ \\
\hline & & $\mathrm{SD}(4)$ & 0.488 & -0.094 & -0.002 & -1.011 & $-0.620 * *$ \\
\hline & & AH (5) & -0.586 & -0.205 & 0.002 & 1.135 & $0.346^{*}$ \\
\hline \multirow{12}{*}{$\begin{array}{c}\text { Thousand grain } \\
\text { weight }\end{array}$} & \multirow{4}{*}{$\mathrm{N}_{0}$} & rainfall (2) & -0.878 & 0.082 & -0.441 & 0.379 & $-0.858 * *$ \\
\hline & & GDD $>10^{\circ} \mathrm{C}$ & 0.213 & -0.336 & 0.069 & 0.109 & 0.055 \\
\hline & & $\mathrm{SD}(4)$ & 0.555 & -0.033 & 0.698 & -0.445 & $0.774 * *$ \\
\hline & & $\mathrm{AH}(5)$ & -0.666 & -0.073 & -0.622 & 0.500 & $-0.862 * *$ \\
\hline & \multirow[b]{2}{*}{ single } & rainfall (2) & -0.504 & -0.044 & -0.432 & 0.190 & -0.790 ** \\
\hline & & $\mathrm{GDD}>10^{\circ} \mathrm{C}$ & 0.122 & 0.180 & 0.068 & 0.054 & $0.425 * *$ \\
\hline & \multirow{2}{*}{$\mathrm{N}_{60-180}$} & $\mathrm{SD}(4)$ & 0.319 & 0.018 & 0.684 & -0.223 & $0.798 * *$ \\
\hline & & $\mathrm{AH}(5)$ & -0.383 & 0.039 & -0.610 & 0.251 & $-0.703 * *$ \\
\hline & & rainfall (2) & -0.714 & -0.003 & -0.597 & 0.475 & $-0.840^{* *}$ \\
\hline & & GDD $>10^{\circ} \mathrm{C}$ & 0.174 & 0.014 & 0.093 & 0.136 & $0.418 *$ \\
\hline & $\mathrm{N}, \mathrm{N}$ & $\mathrm{SD}(4)$ & 0.451 & 0.001 & 0.946 & -0.558 & $0.840 * *$ \\
\hline & & $\mathrm{AH}(5)$ & -0.542 & 0.003 & -0.843 & 0.626 & $-0.756 * *$ \\
\hline
\end{tabular}

Notes. GDD $>10^{\circ} \mathrm{C}-$ the baseline temperature used for growing degree days computation was $10^{\circ} \mathrm{C}, \mathrm{SD}-$ sunshine duration, $\mathrm{AH}$ - air humidity. Numbers in bold - direct effect, numbers in Italic - dominant effect. * $*^{* *}$ - correlation is significant at $P \leq 0.05$ and $P \leq 0.01$, respectively. 
from Pxy $=0.553\left(\right.$ GDD $>10^{\circ} \mathrm{C}$ at split $\mathrm{N}_{90}$ and $\left.\mathrm{N}_{150}\right)$ to Pxy $=-0.273$ (precipitation at $\mathrm{N}_{0}$ level) (Table 8). Precipitation had negligible negative direct effect on grain yield $(\mathrm{Pxy}=-0.273$ and $\mathrm{Pxy}=-0.109)$ at $\mathrm{N}_{0}$ and $\mathrm{N}_{60-180}$ levels, respectively. Positive dominant indirect effects of $\mathrm{AH}\left(\mathrm{rx}_{2} \mathrm{x}_{5} \mathrm{Px}_{2} \mathrm{y}=0.282\right.$ and $\left.\mathrm{rx}_{2} \mathrm{x}_{5} \mathrm{Px}_{2} \mathrm{y}=0.338\right)$ mitigated untoward action of rainfall increase. Moreover, at $\mathrm{N}_{0}$ and $\mathrm{N}_{60-180}$ levels the effect of $\mathrm{AH}$ on grain yield was direct, dominant and positive $(\mathrm{Pxy}=0.372$ and $\mathrm{Pxy}=$ $0.445)$. At split $\mathrm{N}_{90}, \mathrm{~N}_{150}$ level, the highest positive direct effect on grain yield was shown by GDD $>10^{\circ} \mathrm{C}(\mathrm{Pxy}=$ $0.533)$ and by $\mathrm{SD}(\mathrm{Pxy}=0.408)$.

At $\mathrm{N}_{0}$ level, the direct effects of meteorological factors on ears $\mathrm{m}^{-2}$ ranged from Pxy $=0.792$ (precipitation) to Pxy $=-0.530(\mathrm{AH})$. The effects of SD (Pxy $=0.686)$ and GDD $>10^{\circ} \mathrm{C}(\mathrm{Pxy}=0.677)$ on ears $\mathrm{m}^{-2}$ were direct and dominant. At $\mathrm{N}_{60-180}$ level, significant correlation (sum of entire path of individual meteorological factors) of ears $\mathrm{m}^{-2}$ was identified with weather conditions. However, the highest dominant, direct and positive effect on ears $\mathrm{m}^{-2}$ was expressed by SD $(\mathrm{Pxy}=1.004)$. Moreover, dominating indirect influence of SD adjusted direct effects of the rest of the weather factors on ear $\mathrm{m}^{-2}$. At split $\mathrm{N}_{90}, \mathrm{~N}_{150}$, direct dominant effect on ears $\mathrm{m}^{-2}$ was shown by SD (Pxy $=0.751)$ and GDD $>10^{\circ} \mathrm{C}(\mathrm{Pxy}=0.425)$. Rainfall also revealed positive direct effect $(\mathrm{Pxy}=0.162)$ on ears $\mathrm{m}^{-2}$, but negative contribution of the rest of the weather factors caused negative correlation coefficient $(r=-0.530)$. Inverse correlation between ears $\mathrm{m}^{-2}$ and $\mathrm{AH}(r=-0.605)$ also resulted from negative dominant indirect SD effect $\left(\mathrm{rx}_{5} \mathrm{x}_{4} \mathrm{Px}_{5} \mathrm{y}=-0.670\right)$. At $\mathrm{N}_{0}$ level effects of rainfall, GDD $>10^{\circ} \mathrm{C}$ and $\mathrm{AH}$ were direct and dominant. Unfortunately, direct effects of rainfall and $\mathrm{AH}$ were sharply reduced by the rest of the meteorological indices. Consequently their correlation, i.e. sum of entire path was insignificant ( $r=$ -0.113 and $r=-0.022$, respectively). The direct effect of $\mathrm{SD}$ was negligible $(\mathrm{Pxy}=0.023)$. At single $\mathrm{N}_{60-180}$ level, the direct effects of all meteorological factors on grains ear $^{-1}$ were negative and ranged from Pxy $=-0.363$ to Pxy $=-1.192$. SD revealed the highest direct and dominant impact on grains ear $^{-1}($ Pxy $=-1.192$ and $r=-0.486)$. In split $\mathrm{N}_{00}, \mathrm{~N}_{150}$ level, rainfall had direct negative effect $(\mathrm{Pxy}=-0.772)$ on grains ear ${ }^{-1}$, but it was mitigated by positive dominating indirect effect of AH $(\mathrm{Pxy}=0.861)$. Accordingly, the correlation between rainfall and grains ear ${ }^{-1}$ was weak and insignificant $(r=0.320)$. The negative inverse correlation between grains ear ${ }^{-1}$ and GDD $>10^{\circ} \mathrm{C}$ at same fertilization level was caused by dominant direct effect on GDD $>10^{\circ} \mathrm{C}(\mathrm{Pxy}=-0.945)$. The correlation between SD and grains ear-1 also was inverse because of the high indirect impact of $\mathrm{AH}\left(\mathrm{rx}_{4} \mathrm{x}_{5} \mathrm{Px}_{4} \mathrm{y}=-1.011\right)$. The impact character of $\mathrm{AH}$ on grains ear $^{-1}$ was direct and dominant $(\mathrm{Pxy}=1.135)$; however, it was mitigated by indirect effect of rainfall $\left(\mathrm{rx}_{5} \mathrm{x}_{2} \mathrm{Px}_{5} \mathrm{y}=-0.586\right)$.

Rainfall had negative dominant direct effects on TGW at all $\mathrm{N}$ levels (Pxy $=-0.878,-0.504$ and -0.714 ) and this caused the inverse significant correlation between these two parameters. In all $\mathrm{N}$ levels, SD had positive dominant direct effect on TGW (Pxy $=0.698,0.684$ and 0.946). The sum of meteorological factors entire paths (i.e. correlation between TGW and SD) also was high and significant $(r=0.774,0.798$ and 0.840$)$. Positive character of AH direct effect on TGW was sharply changed by all of the rest of meteorological factors. Consequently, the correlation between TGW and $\mathrm{AH}$ at all $\mathrm{N}$ levels assumed inverse significant dependence.

Path coefficients analysis appears to be a useful tool for understanding grain yield formation and provides valuable additional information for improving grain yield via formation of its components during growing season.

\section{Conclusions}

1. The correlation matrix between spring triticale grain yield and yield components did not reveal significant causality at $\mathrm{N}_{0}$ level. Under single $\mathrm{N}_{60-180}$ fertilization, grain yield of spring triticale depended on ears $\mathrm{m}^{-2}$ and thousand grain weight (TGW). Under split $\mathrm{N}_{90}, \mathrm{~N}_{150}$ level the yield depended on ears $\mathrm{m}^{-2}$. However, the increase of the grains ear ${ }^{-1}$ in a dense stand caused a negative influence on the yield.

2. TGW and grains ear ${ }^{-1}$ were dominant factors for yield formation at $\mathrm{N}_{0}$ level; TGW - at single $\mathrm{N}_{60-180}$ level; and ears $\mathrm{m}^{-2}$ and grains ear ${ }^{-1}$ - at split $\mathrm{N}_{90}$ and $\mathrm{N}_{150}$ level.

3. The character of interaction of grain yield components influenced the grain yield by $17.2 \%$ and $28.3 \%$ at single $\mathrm{N}_{60-180}$ and split $\mathrm{N}_{90}, \mathrm{~N}_{150}$ fertilization levels, respectively; 60 however, such interaction was insignificant at $\mathrm{N}_{0}$ level.

4. The influence of meteorological factors on grain yield and its components was more pronounced in fertilized treatments. The growth and development of spring triticale responded to meteorological conditions more sensitively at single $\mathrm{N}_{60-180}$ and split $\mathrm{N}_{90}, \mathrm{~N}_{150}$ levels than at $\mathrm{N}_{0}$ level.

5. According to multiple regression analysis, the interaction of all meteorological factors influenced the grain yield by $25.6 \%$ and $40.7 \%$ at $\mathrm{N}_{60-180}$ and split $\mathrm{N}_{90}$, $\mathrm{N}_{150}$ levels, respectively. At all $\mathrm{N}$ regimes, the weather conditions caused $72.6-83.5 \%$ of ears $\mathrm{m}^{-2}, 46.6-94.1 \%$ of grains ear ${ }^{-1}$ and $84.5-92.7 \%$ of TGW data variation.

\section{Acknowledgements}

The paper presents research findings, obtained through the long-term research programme "Biopotential and quality of plants for multifunctional use" implemented by Lithuanian Research Centre for Agriculture and Forestry.

Received 10102013 Accepted 19092014

\section{References}

Alaru M., Laur Ü., Jaama E. 2003. Influence of nitrogen and weather conditions on the grain quality of winter triticale. Agronomy Research, 1 (1): 3-10

Ali M. A., Hussain M., Khan M. I., Ali M., Zulkiffal M. Anwar W., Sabir W., Zeeshan M. 2010. Source-sink relationship between photosynthetic organs and grain yield attributes during grain filling stage in spring wheat (Triticum aestivum). International Journal of Agriculture and Biology, 12 (4): 509-515

Ashfaq M., Khan A. S., Ali Z. 2003. Association of morphological traits with grain yield in wheat (Triticum aestivum L.). International Journal of Agriculture and Biology, 5 (3): 262-264

Erekul O., Köhn W. 2006. Effect of weather and soil conditions on yield components and bread-making quality of winter wheat (Triticum aestivum L.) and winter triticale (Triticosecale Wittm.) varieties in North-East Germany. Journal of Agronomv and Cron Science. 192: 452-464 http://dx.doi.org/10.1111/j.1439-037X.2006.00234.x

Estrada-Campusano G., Slafer G., Miralles D. J. 2012. Differences in yield, biomass and their components between triticale and wheat grown under contrasting water and nitrogen environments. Field Crons Research, 128: 167-179 http://dx.doi.org/10.1016/j.fcr.2012.01.003

FAO, ISRIC and ISSS. 1998. World reterence base for soil resources. FAO, Rome

Feizienè D., Feiza V., Subačienè G. 2004. The influence of different tillage - fertilization systems on winter wheat yield and its biological parameters on loamy soils in Central Lithuania. Zemdirbyste-Agriculture, 85 (1): 83-101 (in Lithuanian)

Felenji H., Ahmadizadeh M. 2011. Evaluating yield and some traits of potato cultivars in fall cultivation of Jiroft area. Journal of Applied Environmental and Biological Sciences, 1 (12): 643-649 
Garcia del Moral L. F., Rharrabti Y., Villegas D., Royo C. 2003. Evaluation of grain yield and its components in durum wheat under Mediterranean conditions: an ontogenic annroach. Agronomy .Journal, 95: 266-274 http://dx.doi.org/10.2134/agronj2003.0266

Garcia del Moral L. F., Rharrabti Y., Elhani S., Martos V., Royo C. 2005. Yield formation in Mediterranean durum wheat under two contrasting water regimes based on pathcoefficient analysis. Funhytica, 146 (3): 203-212 http://dx.doi.org/10.1007/s10681-005-9006-2

Janušauskaitè D. 2008. Winter triticale yield and quality depending on nitrogen fertilization and meteorological conditions. Žemès ūkio mokslai, 15 (4): 21-27 (in Lithuanian)

Kozak M., Kang M. S. 2006. Note on modern path analysis in application to crop science. Communications in Biometry and Cron Science 1 (1) 3)-34 http://dx.doi.org/10.108́8/09064710600931230

Kozak M., Samborski S., Rozbicki J., Madry W. 2007. Winter triticale grain yield, a comparative study of 15 genotypes. Acta Agriculturae Scandinavica, Section B: Plant and Soil Science, 57 (1): 263-270

Leilah A. A., Al-Khateeb S. A. 2005. Statistical analysis of wheat yield under drought conditions. Journal of Arid Fnvironments, 61: 483-496 http://dx.doi.org/10.1016/j.jaridenv.2004.10.011

Lopez-Bellido L., Lopez-Bellido R. J., Castillo J. E., LopezBellido F. J. 2004. Chickpea response to tillage and soul residual nitrogen in a continuous rotation with wheat. I. Riomass and seed vield. Field Cron Research, 88: 191-200 http://dx.doi.org/10.1016/j.fcr.2004.01.011

Obuchowski W., Bbanaszak Z., Makowska A., Luczak M. 2010. Factors affecting usefulness of triticale grain for bioethanol production. Journal of the Science of Food and A oriculture $90(14) \cdot 2506-7511$ http://dx.doi.org/10.1002/jsfa.4113

Okuyama L. A., Federizzi L. C., Neto J. F. B. 2004. Correlation and path analysis of yield and its components and plant traits in wheat. Ciência Rural, 34 (6): 1701-1708 http://dx.doi.org/10.1590/S0103-84782004000600006

Pecio A. 2010. Productivity of triticale affected by nitrogen fertilization and weather conditions. Fertilizer and Fertilization, 40: 101-116
Peymaninia Y., Valizadeh M., Shahryari R., Ahmadizadeh M., Habibpour M. 2012. Relationship among morphophysiological traits in bread wheat against drought stress at presence of a Leonardite derived humic fertilizer under greenhouse condition. International Research Journal of Applied and Basic Sciences, 3 (4): 822-830

Royo C., Abaza M., Blanco R.,García del Moral L. F. 2000. Triticale grain growth and morphometry as affected by drought stress, late sowing and simulated drought stress. Australian Journal of Plant Physiology, 27 (11): 1051-1059

Snedecor G. W., Cochran W. G. 1981. Statistical methods ( $7^{\text {th }}$ ed.). Iowa, USA

Sokoto M. B., Abubakar I. U., Dikko A. U. 2012. Correlation analysis of some growth, yield, yield components and grain quality of wheat (Triticum aestivum L.). Nigerian Journal of Basic and Applied Science, 20 (4): 349-356

Subhani G. M., Chowdhry M. A. 2000. Correlation and path coefficient analysis in bread wheat under drought stress and normal conditions. Pakistan Inurnal of Biological Sciences, 3 (1): 72-77 http://dx.doi.org/10.3923/pjbs.2000.72.77

Tarakanovas P., Raudonius S. 2003. Agronominių tyrimų duomenu statistine analize taikant kompiuterines programas $A N O V A$, STAT, SPLIT-PLOT iš paketo SEKELCIJA ir IRRISTAT. Lithuanian University of Agriculture, 58 p. (in Lithuanian)

Ugarte C., Calderini D. F., Slafer G. A. 2007. Grain weight and grain number responsiveness to pre-anthesis temperature in wheat, harley and triticale. Field Crons Research, 100: 240-248 http://dx.doi.org/10.1016/j.fcr.2006.07.010

Waqar-ul-Haq, Munir M., Akram Z. 2010. Estimation of interrelationships among yield and yield related attributes in wheat lines. Pakistan Journal of Botany, 42 (1): $567-$ 573

Villegas D., Casadesus J., Atienza S., Martos V., Maalouf F., Karam F., Aranjuelo I., Nogues S. 2010. Tritordeum, wheat and triticale yield components under multi-local Mediterranean drought conditions. Field Crons Research, 116: 68-74 http://dx.doi.org/10.1016/j.fcr.2009.11.012

Wright S. 1960. Path coetticients and path regressions: alternative or comnlementary concents? Biometrics, 16 (2): 189-202 http://dx.doi.org/10.2307/2527551

ISSN 1392-3196 / e-ISSN 2335-8947

Zemdirbyste-Agriculture, vol. 101, No. 4 (2014), p. 381-388

DOI $10.13080 / \mathrm{z}-\mathrm{a} .2014 .101 .048$

\title{
Vasarinių kvietrugių derliaus ir jo komponentų analizė skirtingai tręšiant azotu
}

\author{
D. Janušauskaitė
}

Lietuvos agrarinių ir miškų mokslų centro Žemdirbystès institutas

\section{Santrauka}

Grūdų derlių lemia derliaus struktūros elementai, kurie yra labai jautrūs aplinkos sąlygų pokyčiams. Todèl vis dar trūksta tyrimų duomenų, paaiškinančių ryšį tarp grūdų derliaus ir jị lemiančių veiksnių. Tyrimų tikslas - įvertinti ryšius tarp vasarinių kvietrugių grūdų derliaus ir derliaus struktūros elementų, taikant skirtingą tręšimą azotu, nustatyti meteorologinių veiksnių ịtaką jiems ir taikant tiesioginius bei netiesioginius Taku analizès efektus paaiškinti ryšiu tarp šių rodiklių priežastingumą. Eksperimentas atliktas Lietuvos agrarinių ir miškų mokslų centro Žemdirbystès institute lengvo priemolio giliau karbonatingame giliau glejiškame rudžemyje (RDg4-k2). Kvietrugiai tręšti vienkartinėmis normomis azoto trąšų $\left(\mathrm{N}_{60-180}\right)$, jas išberiant prieš sẻją, $\mathrm{N}_{90}$ bei $\mathrm{N}_{150}$, tręšiant per du ir tris kartus, ir auginti be $\mathrm{N}$ trąšuc $\left(\mathrm{N}_{0}\right.$, kontrolinis variantas). Duomenys įvertinti koreliacijos ir Taku analizių metodais.

Nustatyta, kad grūdų derliaus ir jo struktūros elementų tarpusavio ryšys buvo nevienodas taikant skirtingą tręšimą azotu. Patręšus pagal vienkartine normą $\mathrm{N}_{6-1}$, grūdu derliui didžiausios įtakos turejo varpu skaičius $\mathrm{m}^{-2}$ ir 1000 grūdų masè, o trąšų normą išskaidžius į $\mathrm{N}_{90}{ }_{1 r}^{60-10} \mathrm{~N}_{150}$, išryškejjo didesnè varpų skaičiaus $\mathrm{m}^{-2}$ ịtaka derliui. Koreliacinè matrica tarp meteorologiniu veiksniu ir derliaus bei jo elementu neatskleidè esminès įtakos nenaudojant trąšų. Derliaus struktūros elementai turèjo ịtakos 17,2 ir 28,3\% derliaus duomenų, taip pat ir vienkartinio tręšimo $\mathrm{N}_{60-180}$ ir $\mathrm{N}_{90}$ bei $\mathrm{N}_{150}$ normų išskaidymo variantuose. Meteorologinių veiksnių įtaka vasarinių kvietrugių augimui ir vystymuisi buvo labiau išreikšta azotu tręštų variantų laukeliuose nei juos auginant be trąšų. Nepriklausomai nuo tręšimo, oro sąlygos lèmė 72,6-83,5\% produktyvių stiebų $\mathrm{m}^{-2}, 46,6-94,1 \%$ grūdų varpoje ir 84,5-92,7\% 1000 grūdų masės duomenų variacijos. Meteorologinių veiksnių sąveika vienu kartu patręšus $\mathrm{N}_{60-180}$ lèmė 25,6\%, o $\mathrm{N}_{90}$ ir $\mathrm{N}_{150}$ normas išskaidžius $-40,7 \%$ derliaus.

Reikšminiai žodžiai: azotas, derliaus elementai, meteorologiniai veiksniai, tręšimas. 